\title{
CHEMICAL COMPOSITION AND BIOLOGICAL ACTIVITY OF THE PLUM SEED EXTRACT
}

Ivan M. Savić ${ }^{1^{*}}$, Vesna D. Nikolić1, Ivana M. Savić-Gajić ${ }^{1}$, Tatjana D. Kundaković², Tatjana P. Stanojković ${ }^{3}$, Stevo J. Najman ${ }^{4}$

${ }^{1}$ Faculty of Technology, University of Niš, Leskovac, Serbia,

2Faculty of Pharmacy, University of Belgrade, Belgrade, Serbia,

3 Institute of Oncology and Radiology of Serbia, Belgrade, Serbia,

${ }^{4}$ Institute of Biology and Human genetics, Faculty of Medicine, University of Niš, Niš, Serbia.

The aim of this paper was to estimate the biological activity of the plum seed extract and to define the chemical composition by using the ESI-MS method. During the investigation of the antioxidant activity, the extract showed a better ability to inhibit DPPH radicals compared with amygdalin standard. The results of the antimicrobial study indicate that the extract has a greater effect on Gram-negative bacteria compared with amygdalin. Gram-positive bacteria and fungi remained resistant in both cases. Unlike amygdalin, the extract showed a greater antimicrobial activity against the same microbiological strains. Amygdalin was isolated from the extract before the investigation of antiproliferative activity against MDA-MB-361, MDA-MB-453, HeLa and LS174 cell lines using MTT assay. Unlike the MDA-MB-453 cell line, the activity of standard and isolated amygdalin was not observed at the concentrations lower than $400 \mu \mathrm{g} \mathrm{cm}^{-3}$ on MDA-MB-361 cell line. The isolated amygdalin has not shown the activity in other cell lines. The antiproliferative activity of amygdalin standard was also noticed on HeLa and LS-174 cell lines at the concentrations of 333.27 and $333.17 \mu \mathrm{g} \mathrm{cm}^{-3}$, respectively.
(ORIGINAL SCIENTIFIC PAPER) UDC 547.918:634.22:615.32

Keywords: plum seeds; amygdalin; antioxidant activity; antimicrobial activity; antiproliferative activity.

\section{Introduction}

Despite a great progress in diagnosis and treatment of malignant tumors, this disease is still one of the causes of death in humans [1]. Today, for the treatment of this disease, the numerous chemotherapeutic preparations can be found on the market. Due to their toxicity, most of the chemotherapy drugs cannot be applied at the doses that can completely inhibit the growth of tumor cells in the organism. Lately, the investigations have been focused on the application of herbal agents, including amygdalin, in the treatment of these diseases. Amygdalin is a natural chemotherapy agent which can be found in more than 1,200 plants, particularly in the seeds of fruits such as apricots, peaches, plums and apples [2]. Actually, it is cyanogen glycoside that contains two glucose molecules in its structure, benzaldehyde (an analgesic) and the cyanide group [3]. Pharmacological studies of amygdalin were mainly related to isolated amygdalin, mostly from apricot (Prunus armeniaca) seeds [4]. In pre-clinical studies, Hwang et al. [5] proved that amygdalin from Prunus armeniaca has an anti-inflammatory activity. In addition, the antibacterial activity of amygdalin isolated from Prunus armeniaca was also confirmed [6]. In traditional Chinese medicine, it is known that the seed of Persicae, which contains amygdalin as a major component, can be used in treating the symptoms of atherosclerosis [7].
Having this in mind, Jiagang et al. [8] confirmed the therapeutic potential of amygdalin in preventing and/or treating atherosclerosis. Recently, Khallouki et al. [9] investigated the phytochemical composition and antioxidant capacity of various botanical parts of Mirabelle plums from the territories of France, Germany and Luxembourg. Using the HPLC-ESI-MS method, they defined that the content of amygdalin was over $90 \%$ of the phenolic compounds present in the seeds. Using DPPH, FRAP and ORAC assays, it has been observed that amygdalin from these plant materials did not show any antioxidant activity. It is known that amygdalin is highly efficient in "catching" hydroxyl radicals. This characteristic allows the application of amygdalin as a supplement against anti-aging of the human body [10]. In the late 70's and early 80's of the 20th century, it was confirmed that amygdalin shows the antitumor activity in addition to the above mentioned effects. It is believed that amygdalin is a major non-toxic agent for the metabolic treatment of cancer. Although the application of amygdalin has limitations, this bioactive compound has shown to be suitable against tumors of the lungs, breast, prostate, colon and lymphomas [11-13]. Jiagang et al. [8] activated amygdalin using $\beta$-D-glucosidase enzyme and monitored its effect on Hep G2 proliferative cells. Actually, amygdalin

\footnotetext{
*Author address: Ivan M. Savić, Faculty of Technology, University of Niš, Bulevar oslobodjenja 124, 16000 Leskovac, Serbia.

E-mail: ici_teh@yahoo.com

The manuscript received: October, 05, 2016.

Paper accepted: November, 07, 2016.
} 
has prevented the growth of these cells more strongly after its activation. The extract of Persicae semen, which contains amygdalin as a major bioactive compound, was tested on the proliferative cells of leukemia (HL-60). It was found that amygdalin had the cytotoxic effect on HL60 with $\mathrm{IC}_{50}$ of $6.4 \mathrm{mg} \mathrm{cm}^{-3}$ in the presence of $250 \mathrm{nM}$ $\beta$-D-glucosidase [14].

The data about the investigation of the pharmacological activity of the plum seed extract, and amygdalin isolated from this plant material cannot be found in literature. Due to these reasons, the aim of this paper was to investigate the antioxidant and antimicrobial activity of the plum seed extract, as well as the antiproliferative activity of isolated amygdalin. The qualitative identification of bioactive compounds in the plum seed extract was performed using ESI-MS method.

\section{Experimental}

\section{Reagents}

Amygdalin standard purity of $97 \%$ (Sigma-Aldrich, Steinheim, Germany), 2,2-diphenyl-1-picrylhydrazyl (DPPH), a powder medium RPMI 1640, dimethylsulfoxide (DMSO), sodium dodecyl sulfate (SDS), 3-[4,5-dimethyl(thiazol-2yl)-3,5-diphery] tetrazolium bromide (MTT), L-glutamine, streptomycin, penicillin, gentamicin (Sigma Chemical Company, St. Louis, USA), fetal bovine serum (FBS) (Gibco BRL, New York, USA), butylated hydroxytoluene-BHT (Centrohem, Stara Pazova, Serbia), absolute ethanol (Alkaloid AD, Skopje, Republic of Macedonia), 96\% (v/v) ethanol (Zorka Pharma, Sabac, Serbia), diethyl ether ( $\geq 99 \%$ ) (VWR International, Lutterworth, UK).

\section{Plant material}

Fresh plum seeds (Pruni domesticae semen) was purchased from PD Plemic-commerce (Osecina, Serbia) and dried in a dark place up to the $6 \%$ moisture content. The plant material was ground in an electric mill in order to obtain a fine powder with an average particle size of $0.3 \mathrm{~mm}$.

\section{Extraction procedure}

The plant material was transferred to the round flask of $100 \mathrm{~cm}^{3}$ and absolute ethanol was added in the solid-to-liquid ratio of 1:25 (m/v). The extraction was performed under reflux at the temperature of $34.4{ }^{\circ} \mathrm{C}$. The system temperature was kept constant using a water bath. These operating conditions were applied according to the previously performed optimization study for amygdalin extraction from this plant material using artificial neural network [15]. During the optimization study, the used neural network was a multilayer perceptron MLP (4-3-1) with the exponential function in the hidden layer and the linear function in the output layer. The extract was separated from the solid matrix by filtration on a Buchner funnel. The liquid extract was evaporated in order to remove the residual ethanol on a vacuum rotary evaporator at $50^{\circ} \mathrm{C}$. The extract was kept in a desiccator until complete drying, i.e. to a constant mass.

\section{ESI-MS/MS analysis}

In order to define the qualitative composition of the plum seed extract under optimal conditions, the electrospray ionization coupled with the mass spectrometry method was applied for this analysis. The mass spectra were done on Thermo Scientific LTQ XL Linear Ion Trap Mass Spectrometer (San Jose, California, USA). The performances of this device enable the identification of the components in the extract without their previous HPLC separation. The presence of bioactive compounds was confirmed based on literature data for mass patterns of the analyzed compounds $[9,16]$. The sample was ionized using an electrospray (ESI) technique. After ionization, the molecular ions of desired compounds were extracted in the analyzer and treated with the adequate portions of collision energy in order to obtain their MS2 spectra. Mass spectra were recorded depending on the analyte nature in positive and negative ionization modes. The used operating conditions were: ion source voltage of $4.95 \mathrm{kV}$, ion current of $2.61 \mu \mathrm{A}$, the capillary temperature of $275^{\circ} \mathrm{C}$, and voltage of $-50 \mathrm{~V}$, the sheath pressure of $137.14 \mathrm{kPa}$ and auxiliary gas pressure of $13.93 \mathrm{kPa}$. The MS parameters of this method were adjusted using amygdalin standard. Xcalibur software was used for data collection and analysis.

\section{Preparation of the sample for MS analysis}

The stock solutions of amygdalin standard and plum seed extract were prepared by dissolving $25 \mathrm{mg}$ of the sample in $25 \mathrm{~cm}^{3}$ of methanol. After that, the solutions were diluted from the stock solution to the concentration of $3 \mathrm{\mu g} \mathrm{cm}^{-3}$ with the addition of the formic acid $\left(0,05 \mathrm{~cm}^{3}\right)$. The prepared solutions were injected into the MS spectrometer.

Determination of antioxidant activity (DPPH assay)

The procedure of DPPH assay is based on the preparation of a stock solution of investigated samples and on its dilution to make a series of solutions. In this study, the initial concentrations of amygdalin standard, plum seed extract, and BHT were $2.5 \mathrm{mg} \mathrm{cm}^{-3}, 0.8 \mathrm{mg} \mathrm{cm}^{-3}$ and $0.25 \mathrm{mg} \mathrm{cm}^{-3}$, respectively. The prepared solutions $\left(2.5 \mathrm{~cm}^{3}\right)$ were treated with $1 \mathrm{~cm}^{3}$ of the ethanolic solution of DPPH radicals $\left(3 \times 10^{-4} \mathrm{~mol} \mathrm{dm}^{-3}\right)$. After that, the samples were incubated at room temperature in a dark for $20 \mathrm{~min}$. The ethanol solution of DPPH radicals $\left(1 \mathrm{~cm}^{3}\right)$ diluted with $2.5 \mathrm{~cm}^{3}$ of ethanol was used as a blank solution. The absorbance of the samples was measured at $517 \mathrm{~nm}$ against $96 \%$ ethanol. The inhibition of DPPH radicals was calculated based on the Equation 1 [17]:

Inhibition of DPPH radicals $(\%)=100 \times\left(1-\frac{A_{S}-A_{B}}{A_{C}}\right)$

where: $A_{S}-$ absorbance of the samples (ethanol solution of the samples treated with DPPH radicals), $A_{B}-$ absorb- 
ance of the blank (ethanol solution of the samples without addition of DPPH radicals), AC - absorbance of the control (diluted ethanol solution of DPPH radicals).

\section{Determination of antimicrobial activity}

The strains of microorganisms used in this study were Gram-negative (Escherichia coli ATCC 8739, Pseudomonas aeruginosa ATCC 9027) and Gram-positive bacteria (Bacillus subtilis ATCC 6633, Staphylococcus aureus ATCC 6539), as well as fungi (Candida albicans ATCC 10231, Aspergillus braziliensis ATCC 16404). Antibiotic agar $\left(10 \mathrm{~cm}^{3}, \mathrm{pH}\right.$ 6.5) (Sigma Aldrich, Steinheim, Germany) was poured into Petri plates for the bacteria growth, i.e. Sabouraud dextrose agar ( $\mathrm{pH}$ 5.6) (Sigma Aldrich, Steinheim, Germany) for the fungi growth. A medium was previously inoculated with $150 \mu \mathrm{l}$ of the analyzed cells suspension. The suspensions were prepared by diluting the overnight cultures from liquid medium in a $0.9 \% \mathrm{NaCl}$ solution to the average content of $108 \mathrm{CFU} \mathrm{cm}{ }^{-3}$ The cell number was determined using direct microscopic methods. The plates were kept at $4{ }^{\circ} \mathrm{C}$ during $1 \mathrm{~h}$ in order to solidify. After that, the sterile discs (Schleicher \& Schuell, Dassel, Germany) with a diameter of $12.5 \mathrm{~mm}$ were soaked with the ethanolic solutions $(30 \mu \mathrm{l})$ of the plum seed extract and amygdalin standard and placed on the surface of solidified agar plates. Amygdalin standard was prepared in the concentrations of $0.2,0.8$ and $1.6 \mathrm{mg} \mathrm{cm}^{-3}$. Ethanol was used as a negative control. The sensitivity of the strains was also tested to gentamicin in order to compare its antimicrobial activity with the activities of other samples. Bacteria (Gram-positive and Gram-negative) were incubated at $37^{\circ} \mathrm{C}$ for $18-24 \mathrm{~h}$, i.e. fungi were incubated at $25{ }^{\circ} \mathrm{C}$ for $24-48 \mathrm{~h}$ in the anaerobic conditions. After the incubation, the diameters of inhibition zones were measured in millimeters. The values were expressed as the mean value of three measurements.

\section{MTT assay}

The cell lines

HeLa cells (human cervical adenocarcinoma), MDAMB-361 (estrogen-dependent) and MDA-MB-453 (estrogen-independent) cells (human breast cancer), LS174 cells (cells of human colon carcinoma) and healthy MRC-5 cells (human lung fibroblasts).

\section{Nutrient medium}

RPMI 1640 medium with $10 \%$ of the inactivated bovine serum (FBS) at $56{ }^{\circ} \mathrm{C}$, L-glutamine $\left(3 \mathrm{mmol} \mathrm{dm}^{-3}\right)$, penicillin $\left(100 \mathrm{IU} \mathrm{cm}^{-3}\right)$, streptomycin $\left(100 \mathrm{~g} \mathrm{~cm}^{-3}\right)$ and HEPES $\left(25 \mathrm{mmol} \mathrm{dm}^{-3}\right)$ was used for the growth and maintenance of HeLa, LS-174, MRC-5 cell lines. The $\mathrm{pH}$ of medium was adjusted to 7.2 by using the bicarbonate solution. The same medium was used for MDA-MB-361 and MDA-MB-453 cell lines, but with the glucose addition to $1.11 \mathrm{~g} \mathrm{~cm}^{-3}$.

\section{Treatment of cell lines}

The samples were dissolved in DMSO up to the ini- tial concentration of $400 \mu \mathrm{g} \mathrm{cm}^{-3}$. After that, the samples were diluted in the nutrient medium to appropriate working concentrations. Microtiter plates with 96 wells (Nunc, Nalgene, Denmark) were used for the determination of the cell survival. The density of HeLa, MDA-MB-361, MDA-MB-453, LS-174, MRC-5 cells was 2000, 7000, 3000,7000 and 5000 cells per well in $100 \mu$ l of media, respectively. Nutritient medium was used as a blank. After $24 \mathrm{~h}$ from seeding the cells, five different concentrations of samples $(50 \mu \mathrm{l})$ were added to the wells with malignant cells and blanks. Fresh nutrient medium $(50 \mu \mathrm{l})$ was added to control cells and blanks. The final concentrations of the compounds were $400,200,100,50$ and $25 \mathrm{\mu g} \mathrm{cm}^{-3}$. The cells were incubated in a humidified atmosphere $(95 \%$ air, $5 \% \mathrm{CO}_{2}$ ) at $37^{\circ} \mathrm{C}$ for $72 \mathrm{~h}$.

\section{Determination of cells survival}

After the incubation, $20 \mu \mathrm{l}$ of MTT solution ( $5 \mathrm{mg} \mathrm{MTT/}$ $\mathrm{cm}^{3}$ PBS) was added to each well, while $100 \mu \mathrm{l}$ of $10 \%$ SDS was added after $4 \mathrm{~h}$. The absorbance was measured on an ELISA reader at $570 \mathrm{~nm}$. The antiproliferative effect of amygdalin standard and isolated amygdalin in relation to the control culture of malignant cells was monitored in the experiment. The cells survival was calculated according to Equation 2 [18]:

$$
S(\%)=\frac{A_{t}-A_{b}}{A_{c}-A_{b}} \times 100
$$

where: $A_{t}$ - absorbance of the samples with the treated cells, $A_{b}$ - absorbance of the blank, and $A_{c}$ - absorbance of the control.

Actually, $I C_{50}$ concentration is defined as the substance concentration that inhibits $50 \%$ of the cells survival relative to the untreated control.

\section{Results and discussion}

The amygdalin yield was found to be $25.30 \mathrm{~g}$ per $100 \mathrm{~g}$ of the dried extract, which was determined using the HPLC method described by Savic et al. [19]. The antioxidant and antimicrobial activities of the plum seed extract was investigated and compared with the activity of amygdalin standard. Before MTT analysis, the plum seed extract was treated with diethyl ether for the purpose of amygdalin isolation. The solvent was proven as suitable for dissolving the fatty compounds of the extract, while amygdalin was precipitated in the flask as an insoluble polar compound. The precipitated amygdalin was separated by decanting from other compounds in the extract. Its structure was confirmed using various instrumental methods such as UV-Vis, FTIR, ESI-MS methods [15]. This isolated compound was dried in a desiccator before further analysis of its cytotoxic effect on the tested tumor cell lines. The antiproliferative activity of isolated amygdalin was compared with available amygdalin standard.

ESI-MS-MS analysis of the plum seed extract Mass spectrometry method was used for the qualita- 
tive analysis of the plum seed extract. The aim of this analysis was to identify the compounds which could act synergistic and affect the antioxidant and antimicrobial activity of the extract. Based on the mass fragmentation patterns described in literature $[9,16]$, the phenolic and flavonoid compounds were identified in the extract. Khallouki et al. [9] also identified the presence of these compounds in the methanolic extract of plum seeds. The mass fragmentation patterns of the identified compounds are presented in Table 1. The presence of nine bioactive compounds was confirmed in the ethanolic extract of plum seeds. The values of collision energies for each identified compounds are also given in Table 1.

Table 1. The identified bioactive compounds in the plum seed extract using ESI-MS-MS

\begin{tabular}{|c|c|c|c|c|}
\hline Bioactive compound & Structure & {$[\mathrm{M}-\mathrm{H}]^{-}$} & $\begin{array}{c}\text { ESI-MS-MS } \\
\text { fragmentation, } \mathrm{m} / \mathrm{z}\end{array}$ & $\begin{array}{c}\text { Collision } \\
\text { energy, } \\
\text { eV }\end{array}$ \\
\hline benzoic acid & & 121.1 & $106,93.1,77^{*}$ & 22 \\
\hline 4-hydroxybenzoic acid & & 136.9 & $93.1^{*}$ & 19 \\
\hline vanillin & & 151.1 & $136.1,108.1,92.9^{*}$ & 22 \\
\hline $\begin{array}{l}\text { 3,4-dihydroxybenzoic } \\
\text { acid }\end{array}$ & & 153 & $108.8^{*}$ & 16 \\
\hline vanillic acid & & 167.3 & $151.9,123.2,107.9,91.1^{*}$ & 24 \\
\hline gallic acid & & 169.1 & $125^{*}$ & 20 \\
\hline syringaldehyde & & 181 & $\begin{array}{l}\text { 166.2, 151.1, 151.1, } \\
122.7^{\star}\end{array}$ & 23 \\
\hline syringic acid & & 197.3 & $\begin{array}{l}182.1,167,153.3,137.8 \\
122.9,121,106.1^{*}\end{array}$ & 33 \\
\hline & & {$[\mathrm{M}+\mathrm{Na}-\mathrm{H}]^{-}$} & & \\
\hline amygdalin & & 480 & $453,363,374,347^{\star *}$ & 12 \\
\hline
\end{tabular}

From these results, it can be concluded that a parent ion of benzoic acid gives a signal at $m / z 121$, while the fragment ions have signals at $\mathrm{m} / \mathrm{z} 93$ of $[\mathrm{M}-\mathrm{H}]{ }^{-}-\mathrm{CO}$ and at $\mathrm{m} / \mathrm{z} 77$ of $[\mathrm{M}-\mathrm{H}]{ }^{-}-\mathrm{CO}_{2}$. The p-hydroxybenzoic acid in addition to a parent ion at $\mathrm{m} / \mathrm{z} 137$ has a fragment ion at $\mathrm{m} / \mathrm{z}$ 93, which originates from $[\mathrm{M}-\mathrm{H}]-{ }^{-}-\mathrm{CO}_{2}$. The parent ion of vanillin has a signal at $m / z 151$. The fragment ions occurred at $m / z 136$ as a result of the $\mathrm{CH}_{3}$ group loss, i.e. at $m / z 108$ and $m / z 92$ originating from $[\mathrm{M}-\mathrm{H}]{ }^{-}-\mathrm{CH}_{3}-\mathrm{CO}$ and $[\mathrm{M}-\mathrm{H}]--\mathrm{CH}_{3}-\mathrm{CO}-\mathrm{OH}$, respectively. The presence of 3,4-dihydroxybenzoic acid was confirmed based on the signal of the parent ion at $\mathrm{m} / \mathrm{z} 153$ in the mass spectrum. The effect of the collision energy of $16 \mathrm{eV}$ leads to the appearance of a peak at $\mathrm{m} / \mathrm{z} 108.83$ due to a loss of
$\mathrm{CO}_{2}$. When vanillic acid with a molecular mass of 168 is recorded in the negative mode, it gives a peak at $\mathrm{m} / \mathrm{z}$ 167. The action of the collision energy of $24 \mathrm{eV}$ leads to the formation of fragment ions which have signals at $\mathrm{m} / \mathrm{z}$ 152, 123, 108 and 91. The fragment ion at $\mathrm{m} / \mathrm{z} 152$ was caused due to the loss of $\mathrm{CH}_{3}$ group from the parent ion, while the signal at $\mathrm{m} / \mathrm{z} 123$ occurred due to the loss of $\mathrm{CO}_{2}$. The ion at $\mathrm{m} / \mathrm{z} 108$ was formed after losing $\mathrm{CH}_{3}$ and $\mathrm{CO}_{2}$ groups. After further $\mathrm{OH}$ group losing, the signal appeared at $m / z 91$ in the mass spectrum. The gallic acid in its mass spectrum in addition to the parent ion at $\mathrm{m} / \mathrm{z}$ 169 has a peak of the fragment ion at $\mathrm{m} / \mathrm{z} 125$ due to the loss of $\mathrm{CO}_{2}$. The loss of $\mathrm{CH}_{3}$ group from the basic peak of syringaldehyde at $\mathrm{m} / \mathrm{z} 181$ causes the signal at $\mathrm{m} / \mathrm{z}$ 
166. After the loss of two $\mathrm{CH}_{3}$ groups, a new signal at $\mathrm{m} / \mathrm{z}$ 151 is formed. The ion at $\mathrm{m} / \mathrm{z} 123$ occurred after further loss of CO group. Unlike previous two compounds, syringic acid in addition to the parent ion at $m / z 197$ has a large number of the fragment ions at $m / z 182$ of $[\mathrm{M}-\mathrm{H}]^{-}$$\mathrm{CH}_{3}, \mathrm{~m} / \mathrm{z} 167$ of $[\mathrm{M}-\mathrm{H}]^{-}-2 \mathrm{CH}_{3}, \mathrm{~m} / \mathrm{z} 153$ of $[\mathrm{M}-\mathrm{H}]^{-}-\mathrm{CO}_{2}$, $\mathrm{m} / \mathrm{z} 138$ of $[\mathrm{M}-\mathrm{H}]^{-}-\mathrm{CH}_{3}-\mathrm{CO}_{2}, \mathrm{~m} / \mathrm{z} 123$ of $[\mathrm{M}-\mathrm{H}]^{-}-2 \mathrm{CH}_{3}$ $-\mathrm{CO}_{2}, \mathrm{~m} / \mathrm{z} 121$ of $[\mathrm{M}-\mathrm{H}]-\mathrm{CH}_{3}-\mathrm{CO}_{2}-\mathrm{H}_{2} \mathrm{O}$ and $\mathrm{m} / \mathrm{z} 106$ of $[\mathrm{M}-\mathrm{H}]^{-}-2 \mathrm{CH}_{3}-\mathrm{CO}_{2}-\mathrm{H}_{2} \mathrm{O}$ [9]. The basic peak of amygdalin at $\mathrm{m} / \mathrm{z} 480$ occurred due to the formation of an adduct with sodium $[\mathrm{M}+\mathrm{Na}-\mathrm{H}]$. The fragment peaks at $\mathrm{m} / \mathrm{z} 453$ and 363 were the result of losing neutral fragments $\mathrm{HCN}$ and $\mathrm{C}_{8} \mathrm{H}_{7} \mathrm{~N}$ [16]. The most common product at $\mathrm{m} / \mathrm{z} 347$ and the ionic product at $\mathrm{m} / \mathrm{z} 374$ were also noticed because of losing mandelonitrile $\left(\mathrm{C}_{8} \mathrm{H}_{7} \mathrm{NO}\right)$ and $\mathrm{C}_{7} \mathrm{H}_{8} \mathrm{~N}$ from the parent ion at $m / z 480$, respectively.

Antioxidant activity of amygdalin and plum seed extract

DPPH assay was applied to investigate the antioxidant activity of amygdalin standard, plum seed extract and synthetic antioxidant BHT. The inhibition of DPPH radicals depending on the sample concentration is shown in Fig. 1. It can be seen that the increase of the amygdalin concentration leads to more effective DPPH radicals inhibition. The maximum value of DPPH radicals inhibition (52.30\%) was achieved at the amygdalin concentration of $625 \mu \mathrm{g} \mathrm{cm}^{-3}$. Unlike amygdalin that showed a satisfactory antioxidant activity at higher concentrations, the solution of the plum seed extract showed almost the same activity at lower concentrations. The highest inhibition of DPPH radicals of $61.30 \%$ was achieved at the concentration of the plum seed extract of $6.3 \mu \mathrm{g}$ $\mathrm{cm}^{-3}$. The maximum activity of BHT $(80.9 \%)$, which also represents the highest value of the investigated samples, was found to be at the concentration of $120 \mathrm{\mu g} \mathrm{cm}^{-3}$.

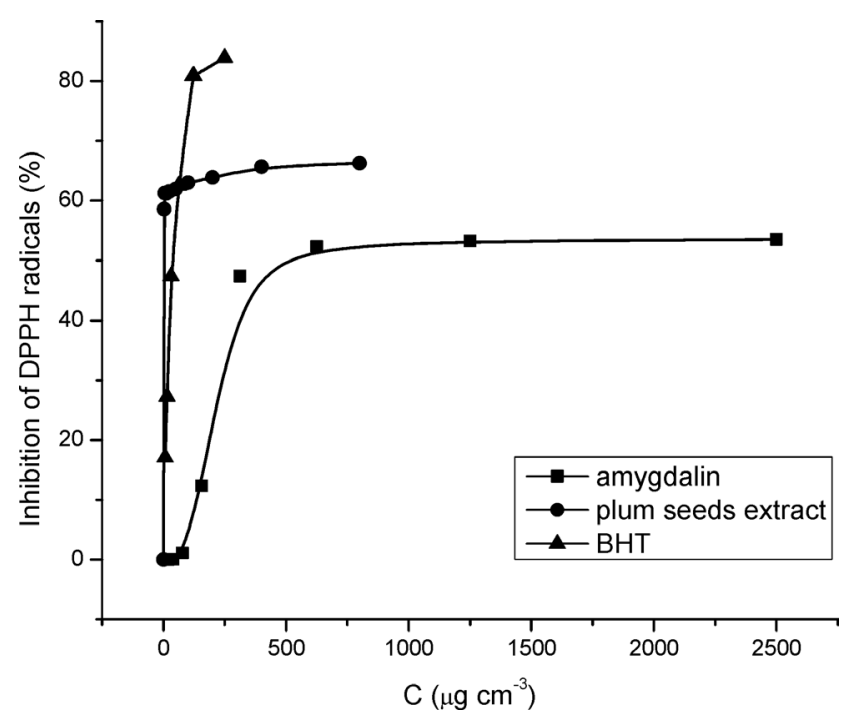

Figure 1. Inhibition of DPPH radicals depending on the concentration of amygdalin standard, plum seed extract and BHT
$E_{50}$ values of the investigated samples were obtained by an interpolation. This value represents the concentration of the samples necessary to inhibit $50 \%$ of the initial concentration of DPPH radicals. The $\mathrm{EC}_{50}$ values of amygdalin $\left(\mathrm{EC}_{50}=477.8 \mu \mathrm{g} \mathrm{cm}^{-3}\right.$ ) is higher than the value obtained for the plum seed extract $\left(E_{50}=2.67 \mu \mathrm{g} \mathrm{cm}^{-3}\right)$, i.e. than the value obtained for $\mathrm{BHT}\left(\mathrm{EC}_{50}=36.6 \mu \mathrm{g} \mathrm{cm}^{-3}\right)$. Based on these results, it can be concluded that amygdalin has a lower ability to inhibit DPPH radicals compared with the analyzed extract and synthetic antioxidant. A better "scavenge"ability of the extract can be attributed to the presence of additional compounds with an expressed antioxidant activity. This group of compounds usually includes flavonoids and phenolic acids. Khallouki et al. [9] investigated the antioxidant activity of the methanol extract of different parts of plum genus Rosaceae (Mirabela) from France, Germany and Luxembourg. The use of DPPH, FRAP and ORAC assays showed that amygdalin as a major compound of the methanol extract did not have the antioxidative activity. Unlike Khallouki et al. [9], the results obtained in our study show that amygdalin and the extract of Stanley plum seeds have a better activity in „scavenging"of DPPH radicals.

Antimicrobial activity of amygdalin and plum seed extract

Antimicrobial activity of amygdalin standard and plum seed extract was tested on six various strains of the microorganism (four bacteria and two fungi) using a disk diffusion method. The concentrations of the analyzed solutions for amygdalin standard were $C_{1}=0.2 \mathrm{mg} \mathrm{cm}^{-3}$; $\mathrm{C}_{2}=0.8 \mathrm{mg} \mathrm{cm}^{-3}$ and $\mathrm{C}_{3}=1.6 \mathrm{mg} \mathrm{cm}^{-3}$. The effect of $96 \%$ $(\mathrm{v} / \mathrm{v})$ ethanol on the microbial growth was also analyzed, because this solvent was used for dissolving the samples. The antimicrobial activity of the samples was compared with the activity of gentamicin. The obtained results are shown in Table 2. The best effect of amygdalin standard was noticed on Gram (-) bacteria, while Gram $(+)$ bacteria and fungi remained resistant to its action. The lowest concentration of amygdalin standard had the smallest effect on Gram (-) bacteria. Among the tested Gram (-) bacteria, $P$. aeruginosa is one of the most sensitive strains on the action of amygdalin standard. The plum seed extract showed the activity only against Gram (-) bacteria. In comparison to the standard, the extract showed a greater antimicrobial activity against the same strains. This is due to the presence of several different classes of compounds (flavonoids, polyphenolic acids and its esters) which probably have the synergistic effects.

In literature, there is a confirmation that the identified compounds in the plum seed extract show the antimicrobial activity. Yurdugül and Bozoglu [20] confirmed that benzoic acid is a major component in a lyophilized sample of wild plum, which is responsible for a good inhibitory activity against the strains of Klebsiella pneumonia, Acinoto iwofii ATCC 19002, Enterobacter faecium ATCC 6057 and E. coli O157:H7-933. Benzoic acid is normally present in almost all fruits including cranberries, plums, 
raspberries, cloves, cinnamon and other fruits and vegetables [21]. The antimicrobial effect of the phenolic component and p-hydroxybenzoic, vanilla, syringic acid and quercetin has been confirmed in literature [22]. Chanwitheesuk et al. [23] have confirmed the effect of gallic acid on some human pathogenic bacteria. It is known that Gram (-) bacteria in the human organism may be a cause of various diseases $[24,25]$ and serious infections $[26,27]$. $P$. aeruginosa is a part of the physiological microflora of the intestines in humans, and also can be found on the skin. Also, it has the ability to create a great number of toxic proteins which can damage the tissue and cause an immunological insufficiency [28]. Today, antibiotics are used in the treatment of the infections caused by $P$. aeruginosa therapy, because this microorganism is sensitive to cephalosporin antibiotics (cefotaxime, ceftriaxone, cefoperazone) and newer aminoglycoside (ami- kacin). Pathogenic forms of $E$. coli are responsible for a wide range of human diseases [29]. Actually, E. coli is responsible for $90 \%$ of urinary tract infections that lead to inflammation of the kidney. Also, it can cause colitis and hemolytic uremic syndrome in humans.

However, in this study it was confirmed that the plum seed extract mainly has the ability to prevent the growth of Gram (-) bacteria ( $P$. aeruginosa and E. coli). The similar antimicrobial activity of the essential oil of apricot seeds against $P$. aeruginosa and $E$. coli was reported by Lee et al. [30]. The obtained results indicate that the plum seed extract can be used for developing new formulations with anti-bacterial or anti-infective effect. A new formulation could be successfully applied for the treatment of infections and other diseases caused by Gram (-) bacteria, such as $P$. aeruginosa and $E$. coli which are resistant to many conventional antibiotics.

Table 2. Antimicrobial activity of amygdalin standard and plum seed extract

\begin{tabular}{lcccccc}
\hline \multicolumn{1}{c}{ Microorganism } & \multicolumn{9}{c}{ Amygdalin standard } & Plum seed & gentamicin & $\begin{array}{c}96 \%(\mathrm{v} / \mathrm{v}) \\
\text { ethanol }\end{array}$ \\
\hline & C1 & C2 & C3 & extract & & - \\
E. coli ATCC 8739 & - & ++ & ++ & +++ & ++ & - \\
P. aeruginosa ATCC 9027 & ++ & +++ & ++++ & ++++ & - & - \\
B. subtilis ATCC 6633 & - & - & - & - & +++ & - \\
S. aureus ATCC 6539 & - & - & - & - & ++ & - \\
C. albicans ATCC 10231 & - & - & - & - & - & - \\
A. brasiliensis ATCC 16404 & - & - & - & - & - & - \\
\hline
\end{tabular}

It does not show antimicrobial activity $(-)$, inhibition zone $<15 \mathrm{~mm}$. A weak antimicrobial activity $(+)$, inhibition zone of $15-16 \mathrm{~mm}$. A moderate antimicrobial activity (++), inhibition zone of $17-19 \mathrm{~mm}$. A high antimicrobial activity (+++), inhibition zone of 20-22 $\mathrm{mm}$. A strong antimicrobial activity $(++++)$, inhibition zone $>23 \mathrm{~mm}$. The standard deviation $\pm 0.5 \mathrm{~mm}$.

Anticancer activity of amygdalin and isolated amygdalin from plum seeds

Tumor cell lines (MDA-MB-361, MDA-MB-453, HeLa, LS-174) were treated with different concentrations of amygdalin standard and isolated amygdalin during analyzing the anti-proliferative effect. In addition to these cell lines, the studies were carried out on healthy MRC-5 cells. A colorimetric test based on the application of tetrazolium salt was used for the investigation of the antiproliferative activity. The test generates a signal depending on a degree of cells activation. The results were read on the ELISA reader with a satisfactory precision. The $\mathrm{IC}_{50}$ values as a measure of effectiveness of a substance in inhibiting the growth and survival of tumor cell lines are presented in Table 3.

The activity of isolated amygdalin and its standard was not observed at the concentrations lower than 400 $\mu \mathrm{g} \mathrm{cm}{ }^{-3}$ for the MDA-MB-361 cell line, while for MDAMB-453 cell lines, the antiproliferative activity was achieved at the concentrations of $304.65 \mu \mathrm{g} \mathrm{cm}-3$ (amygdalin standard) and $379.5 \mu \mathrm{cm}^{-3}$ (isolated amygdalin). The higher $\mathrm{IC}_{50}$ value for isolated amygdalin can be ex- plained based on the fact that the isolate was not completely pure as an available standard. Unlike the isolated amygdalin, amygdalin standard showed the activity towards HeLa and LS-174 cell lines at the concentrations of 333.27 and $333.17 \mu \mathrm{g} \mathrm{cm}^{-3}$, respectively. The obtained results for standard and isolated amygdalin are expected, considering that Syrigos et al. [31] determined the high $\mathrm{IC}_{50}$ value of $40.4 \mathrm{mmol} \mathrm{dm}{ }^{-3}$ for amygdalin on pleomorphic transitional tumor cells (HT1376). This problem was solved with the addition of the $\beta$-D-glucosidase enzyme, wherein amygdalin cytotoxicity increased 25 times. All samples did not show the cytotoxicity on the healthy MRC- 5 cells. These results are significant because they give priority to the obtained extract and isolated amygdalin for the application as the anticancer agents. 
Table 3. $I C_{50}$ values of amygdalin standard and amygdalin isolated from plum seeds

\begin{tabular}{lccccc}
\hline \multicolumn{1}{c}{ Compound } & \multicolumn{5}{c}{$\mathrm{IC}_{50}\left(\boldsymbol{\mu \mathrm { g } \mathrm { cm } ^ { - 3 } )}\right.$} \\
& MDA-MB-361 & MDA-MB-453 & HeLa & LS-174 & MRC-5 \\
\hline isolated amygdalin & $>400$ & $379.5 \pm 10.23$ & $>400$ & $>400$ & $>400$ \\
amygdalin & $>400$ & $304.65 \pm 29.17$ & $333.27 \pm 22.35$ & $333.17 \pm 71.59$ & $>400$ \\
\hline
\end{tabular}

$\mathrm{IC}_{50}$ values are expressed as mean values \pm SD determined through MTT assay in three independent experiments.

\section{Conclusion}

Amygdalin showed a lower antioxidative activity $(52.3 \%)$ compared with the plum seed extract $(61.3 \%)$. Microbiological tests have shown that strains of fungi $(C$. albicans and $A$. brasiliensis) are resistant to the effects of all tested samples. Amygdalin standard and the extract have the antimicrobial activity only to the strains $P$. aeruginosa and $E$. coli. The antiproliferative activity was not observed on MDA-MB-361 cell line unlike MDA-MB-453 cell line at the concentrations of the isolated amygdalin and its standard lower than $400 \mu \mathrm{g} \mathrm{cm}^{-3}$. The isolated amygdalin did not show the anticancer activity on other cell lines. On the other hand, amygdalin standard had the activity on HeLa and LS-174 cell lines at the concentrations of 333.27 and $333.17 \mu \mathrm{g} \mathrm{cm}^{-3}$, respectively. Based on the present results, it can be concluded that the investigated extract has a potential to be used in the pharmaceutical industry for treating various human diseases. A further perspective will be focused on the increase of amygdalin cytotoxicity in the presence of $\beta-D-$ glucosidase enzyme. The aim will be to add this enzyme in order to increase the hydrolysis of amygdalin and to increase the percentage of the released hydrogen cyanide, which is directly responsible for the antiproliferative activity of amygdalin.

\section{Acknowledgments}

This work was supported by the Ministry of Education, Science and Technological Development of the Republic of Serbia under the project TRp-34012.

\section{References}

[1] A. Aporta, E. Catalán, P. Galán-Malo, A. Ramírez-Labrada, M. Pérez, G. Azaceta, L. Palomera, J. Naval, I. Marzo, J. Pardo, A. Anel, Granulysin induces apoptotic cell death and cleavage of the autophagy regulator Atg5 in human hematological tumors, Biochemical Pharmacology, 87(3) (2014) 410 - 423.

[2] I. F. Bolarinwa, C. Orfila, M. R. Morgan, Amygdalin content of seeds, kernels and food products commerciallyavailable in the UK, Food Chemistry, 152 (2014) 133 - 139.

[3] I. Erdogan-Orhan, M. Kartal, Insights into research on phytochemistry and biological activities of Prunus armeniaca L.(apricot), Food Research International, 44(5) (2011) $1238-1243$

[4] D. Frohne, H. J. Pfander, A handbook for doctors, pharmacists, toxicologists, biologists, and veterinarians, 2nd ed., Timber Press, London, 2005, p. 338.

[5] H. J. Hwang, P. Kim, C. J. Kim, H. J. Lee, I. Shim, C. S. Yin, Y. Yang, D. H. Hahm, Antinociceptive effect of amygdalin isolated from Prunus armeniaca on formalin-induced pain in rats, Biological and Pharmaceutical Bulletin, 31(8) (2008) 1559 - 1564.

[6] J. Bruneton, Pharmacognosy, Phytochemistry, Medicinal Plant, 2nd ed., Lavoisier, 1999.

[7] A. Baroni, I. Paoletti, R. Greco, R. A. Satriano, E. Ruocco, M. A. Tufano, J. J. Perez, Immunomodulatory effects of a set of amygdalin analogues on human keratinocyte cells, Experimental Dermatology, 14(11) (2005) 854 - 859.

[8] D. Jiagang, C. Li, H. Wang, E. Hao, Z. Du, C. Bao, J. Lv, Y. Wang, Amygdalin mediates relieved atherosclerosis in apolipoprotein $\mathrm{E}$ deficient mice through the induction of regulatory T cells, Biochemical and Biophysical Research Communications, 411(3) (2011) 523 - 529.

[9] F. Khallouki, R. Haubner, G. Erben, C. M. Ulrich, R. W. Owen, Phytochemical composition and antioxidant capacity of various botanical parts of the fruits of Prunus $x$ domestica $L$. from the Lorraine region of Europe, Food Chemistry, 133(3) (2012) 697 - 706.

[10] J. South, Laetrile-the answer to Cancer, IAS Anti-Aging Bulletion., 4(7) (2000) 10 - 20.

[11] S. Milazzo, S. Lejeune, E. Ernst, Laetrile for cancer: a systematic review of the clinical evidence, Supportive Care in Cancer, 15(6) (2007) 583 - 595.

[12] H. J. Park, S. H. Yoon, L. S. Han, L. T. Zheng, K. H. Jung, Y. K. Uhm, J. H. Lee, J. S. Jeong, W. S. Yim, J. H. Chung, S. P. Hong, Amygdalin inhibits genes related to cell cycle in SNU-C4 human colon cancer cells, World Journal of Gastroenterology, 11(33) (2005) 5156 - 5161.

[13] H. K. Chang, M. S. Shin, H. Y. Yang, J. W. Lee, Y. S. Kim, M. H. Lee, J. Kim, K. H. Kim, C. J. Kim, Amygdalin induces apoptosis through regulation of $\mathrm{Bax}$ and $\mathrm{Bcl}-2$ expressions in human DU145 and LNCaP prostate cancer cells, Biological and Pharmaceutical Bulletin, 29(8) (2006) 1597 - 1602.

[14] K. Hee-Young, H. Seon-Pyo, H. Dong-Hoon, K. J. Hee, Apoptosis induction of Persicae Semen extract in human promyelocytic leukemia (HL-60) cells, Archives of Pharmacal Research, 26(2) (2003) 157 - 161.

[15] I. M. Savic, V. D. Nikolic, I. M. Savic-Gajic, L. B. Nikolic, S. R. Ibric, D. G. Gajic, Optimization of technological procedure for amygdalin isolation from plum seeds (Pruni domesticae semen), Frontiers in Plant Science, 6 (2015) 1-11.

[16] B. Y. Ge, H. X. Chen, F. M. Han, Y. Chen, Identification of amygdalin and its major metabolites in rat urine by LCMS/MS, Journal of Chromatography B, 857(2) (2007) 281 $-286$.

[17] Z. S. Cvetković, V. D. Nikolić, I. M. Savić, I.M. Savić-Gajić, 
L. B. Nikolić, Development and validation of an RP-HPLC method for quantification of trans-resveratrol in the plant extracts, Chemical Industry, 69(6) (2015) 679 - 687.

[18] T. Mosmann, Rapid colorimetric assay for cellular growth and survival: application to proliferation and cytotoxicity assays, Journal of Immunological Methods, 65(1-2) (1983) 55 - 63.

[19] I. M. Savic, V. D. Nikolic, I. M. Savic, L. B. Nikolic, M. Z. Stankovic, Development and validation of HPLC method for the determination of amygdalin in the plant extract of plum kernel, Research Journal of Chemistry and Environment, 16(4) (2012) 80 - 86.

[20] S. Yurdugul, F. Bozoglu, Studies on antimicrobial activity and certain chemical parameters of freeze-dried wild plums (Prunus spp.), Pakistan Journal of Nutrition, 8(9) (2009) 1434 - 1441.

[21] L. M. Ostertag, N. O'Kennedy, G. W. Horgan, P. A. Kroon, G. G. Duthie, B. de Roos, In vitro anti-platelet effects of simple plant-derived phenolic compounds are only found at high, non-physiological concentrations, Molecular Nutrition and Food Research, 55(11) (2011) 1624 - 1636.

[22] N. H. Aziz, S. E. Farag, L. A. Mousa, M. A. Abo-Zaid, Comparative antibacterial and antifungal effects of some phenolic compounds, Microbios, 93(374) (1997) 43 - 54.

[23] A. Chanwitheesuk, A. Teerawutgulrag, J. D. Kilburn, N. Rakariyatham, Antimicrobial gallic acid from Caesalpinia mimosoides Lamk, Food Chemistry, 100(3) (2007) 1044 $-1048$.

[24] R. S. Munford, Sensing gram-negative bacterial lipopolysaccharides: a human disease determinant?, Infection and Immunity, 76(2) (2008) 454 - 465.
[25] A. D. Haffajee, S. S. Socransky, Microbial etiological agents of destructive periodontal diseases, Periodontology 2000, 5(1) (1994) 78 - 111.

[26] X. Li, K. M. Kolltveit, L. Tronstad, I. Olsen, Systemic diseases caused by oral infection, Clinical Microbiology Reviews, 13(4) (2000) 547 - 558.

[27] H. Wisplinghoff, T. Bischoff, S. M. Tallent, H. Seifert, R. P. Wenzel, M. B. Edmond, Nosocomial bloodstream infections in US hospitals: analysis of 24,179 cases from a prospective nationwide surveillance study, Clinical Infectious Diseases, 39(3) (2004) 309 - 317.

[28] G. L. Winsor, D. K. Lam, L. Fleming, R. Lo, M. D. Whiteside, N. Y. Yu, R. E. Hancock, F. S. Brinkman, Pseudomonas Genome Database: improved comparative analysis and population genomics capability for Pseudomonas genomes, Nucleic Acids Research, 526(39) (2011) D596 -600 .

[29] U. Käppeli, H. Hächler, N. Giezendanner, L. Beutin, R. Stephan, Human infections with non-0157 Shiga toxinproducing Escherichia coli, Switzerland, 2000-2009. Emerging Infectious Diseases, 17(2) (2011) 180 - 185.

[30] H. H. Lee, J. H. Ahn, A. R. Kwon, E. S. Lee, J. H. Kwak, Y. $\mathrm{H}$. Min, Chemical composition and antimicrobial activity of the essential oil of apricot seed, Phytotherapy Research, 28(12) (2014) 1867 - 1872.

[31] K. N. Syrigos, G. Rowlinson-Busza, A. A. Epenetos, In vitro cytotoxicity following specific activation of amygdalin by $\beta$-glucosidase conjugated to a bladder cancerassociated monoclonal antibody, International Journal of Cancer, 78(6) (1998) 712 - 719.

\section{Izvod}

\section{HEMIJSKI SASTAV I BIOLOŠKA AKTIVNOST EKSTRAKTA SEMENA ŠLJIVE}

Ivan M. Savić ${ }^{1}$, Vesna D. Nikolić시 Ivana M. Savić-Gajić ${ }^{1}$, Tatjana D. Kundaković ${ }^{2}$ Tatjana P. Stanojković ${ }^{3}$, Stevo J. Najman ${ }^{4}$

\footnotetext{
${ }^{1}$ Tehnološki fakultet, Univerzitet u Nišu, Leskovac, Srbija,

${ }^{2}$ Farmaceutski fakultet, Univerzitet u Beogradu, Beograd, Srbija,

3 Institut za onkologiju i radiologiju Srbije, Beograd, Srbija,

4 Institut za biologiju i humanu genetiku, Medicinski fakultet, Univerzitet u Nišu, Niš, Srbija.
}

Cilj ovog rada bila je procena biološke aktivnosti ekstrakta semena šljive i definisanje hemijskog sastava primenom ESI-MS metode. Tokom ispitivanja antioksidativne aktivnosti, ekstrakt je pokazao bolju sposobnost inhibiranja DPPH radikala u poređenju sa standardom amigdalina. Rezultati antimikrobne studije pokazali su da ekstrakt ima veći uticaj na rast Gram-negativnih bakterija u odnosnu na amigdalin. Gram-pozitivne bakterije i gljivice ostale su rezistentne u oba slučaja. Za razliku od amigdalina, ekstrakt je pokazao veću antimikrobnu aktivnost na iste sojeve mikroorganizama. Amigdalin je izolovan iz ekstrakta pre ispitivanja antiproliferativne aktivnosti na MDA-MB-361, MDA-MB-453, HeLa i LS174 ćelijskim linijama upotrebom MTT testa. Za razliku od MDA-MB-453 ćelijskih linija, aktivnost standarda i izolovanog amigdalina nije uočena na MDA-MB-361 ćelijskim linijama pri koncentracijama nižim od $400 \mu \mathrm{g} \mathrm{cm}^{-3}$. Izolovani amigdalin nije pokazao aktivnost na ostalim ćelijskim linijama. Antiproliferativna aktivnost standarda amigdalina uočena je i na HeLa i LS-174 ćelijskim linijama pri koncentracijama 333.27 i $333.17 \mu \mathrm{g} \mathrm{cm}^{-3}$, respektivno.
(ORIGINALNI NAUČNI RAD) UDK 547.918:634.22:615.32

Ključne reči: seme šljive; amigdalin; antioksidativna aktivnost; antimikrobna aktivnost; antiproliferativna aktivnost. 